\title{
Gebeliğin Intrahepatik Kolestazı ve Maternal-Fetal Sonuçları
}

\section{Intrahepatic Cholestasis of Pregnancy and Maternal-Fetal Results}

\author{
${ }^{1}$ Kemine UZEL, ${ }^{2}$ Filiz BILIR, ${ }^{3}$ Bahar ASTEPE, ${ }^{4}$ Paşa ULUĞ,${ }^{5}$ Yusuf Kemal ARSLAN, ${ }^{4}$ Tunay KIREMITLI \\ ${ }^{1}$ Department of Gynecology and Obstetrics, Erzincan Binali Yildirim University Mengucek Gazi Training and Research Hospital, \\ Erzincan, Turkey \\ ${ }^{2}$ Department of Gynecology and Obstetrics, Kocaeli University, Kocaeli, Turkey \\ ${ }^{3}$ Department of Gynecology and Obstetrics, University of Health Sciences Kocaeli Derince Training and Research Hospital, \\ Kocaeli Turkey \\ ${ }^{4}$ Department of Gynecology and Obstetrics, Erzincan Binali Yildirim University, Medical Faculty, Erzincan, Turkey \\ ${ }^{5}$ Department of Biostatistics, Erzincan Binali Yildirim University, Medical Faculty, Erzincan, Turkey
}

Kemine Uzel : https://orcid.org/0000-0002-4615-5601

Filiz Bilir: https://orcid.org/0000-0002-8961-1304

Bahar Astepe: https://orcid.org/0000-0002-9012-4802

Paşa Uluğ: https://orcid.org/0000-0001-9870-0109

Yusuf Kemal Arslan: https://orcid.org/ 0000-0003-1308-8569

Tunay Kiremitli: https://orcid.org/0000-0002-4531-827X

\begin{abstract}
OZZ
Amaç: Sıklıkla ikinci trimester in sonlarından itibaren ortaya çıkan intrahepatik gebelik kolestazı, gebelik döneminde görülen yaygın bir karaciğer hastalığıdır. Coğraf varyasyonlara bağlı olarak genel insidansı \%1 -\%27,6 arasında değişmektedir. Bu çalışma, üniversite hastanemizde Gebeliğin İntrahepatik Kolestazı tanılı kadınların maternal ve fetal sonuçlarını bildirmeyi amaçladı.

Materyal ve Metot: Çalışma Eğitim ve Araştır ma Hastanemizde, Haziran 2018-Aralık 2020 tarihleri arasınd Gebeliğin İntrahepatik Kolestazı (GIK) ile komplike olan 44 gebede retrospektif olarak yapıldı. Çalışmaya dahil edilen olguların $(n=44)$ demografik özellikleri, karaciğer enzimleri, tanı aldığı gebelik haftası, doğum șekli ve zamanı, doğumda APGAR skorları, yenidoğanın kilosu ve hasta bilgileri hastane kayıtlarından alındı.

Bulgular: Primipar kadın sayıs1 27 (\%61) idi. $4(\% 9,1)$ kadında preeklampsi ve $4(\% 9,1)$ kadında gestasyonel diabetes mellitus (GDM) izlendi. Yenidoğanlardan sadece birinde doğumda 1. ve 5. dakika APGAR scorları sırasıyla 0 ve 0 idi.

Sonuç: Çalışmamızda herhangi bir olumsuz maternal sonuç gözlenmemesine rağmen, bir perinatal ölüm izlendi. GIK'nin bireysel olarak yönetilmesini öneririz. Komplikasyonların önlenmesinde yakın takip ve aktif yönetim gereklidir.

Anahtar Kelimeler: Gebelik, intrahepatik kolestaz, perinatal sonuçlar
\end{abstract}

\section{ABSTRACT}

Objective: Occurring frequently after the late second trimester intrahepatic cholestasis of pregnancy (ICP) is a widespread liver disease in the period of pregnancy. The general incidence of IC depending on the geographic variations, is probably to vary from $1 \%$ to $27.6 \%$. In the study, it was aimed to report the maternal and fetal outcomes of women with ICP at our university hospital center.

Materials and Methods: The study was performed retrospectively on 44 pregnancies complicated by ICP between June 2018 and December 2020, at our Education and Research Hospital. Demographic characteristics, liver enzymes, a gestational week at diagnosis, type and time of delivery, APGAR scores at birth, and newborn weight and information about the patients included in the study were obtained from hospital records.

Results: The number of primiparous women was 27 $(61 \%)$. In $4(9.1 \%)$ women had preeclampsia and $4(9.1 \%)$ women had gestational diabetes mellitus (GDM). Only one of the neonates had Apgar at the birth 1/5,0 and 0 respectively.

Conclusion: In our study one perinatal death was observed, although no adverse maternal outcomes were observed. We recommend that ICP be managed individually. Close monitoring and active management are required in the prevention of complications.

Keywords: Intrahepatic cholestasis, perinatal outcomes, pregnancy

\section{Yayın Bilgisi / Article Info:}

Gönderi Tarihi/ Received: 29/10/202

Kabul Tarihi/ Accepted: 12/01/2022

Online Yayın Tarihi/ Published: 01/03/2022

Erzincan Binali Yildirim University, Mengucek Gazi Training and

Research Hospital, Erzincan, Turkey

Tel: +90 5413142510

E-mail: kemineuzel@hotmail.com 


\section{INTRODUCTION}

Occurring frequently after the late second trimester intrahepatic cholestasis of pregnancy (ICP) is a widespread liver disease in the period of pregnancy. The general incidence of IC depending on the geographic variations, is probably to vary from $1 \%$ to $27.6 \%$, show differences between environmental factors and ethnic groups. ${ }^{1-3}$ In comparison $1.24 \%$ in the Indian population, while this number is $1.46 \%$ in the Pakistani population, white population has a low incident of $0.62 \%{ }^{4}$ in primarily Latina Los Angeles population, it is $5.6 \%{ }^{5}$

Although there is no definite data reported for Turkey, it was reported as $0.86 \%$ in one study and $0.45 \%$ in another study. ${ }^{6,7}$

ICP is defined by biochemical cholestasis with abnormal liver functions, and elevated levels of serum bile acids (BA) in the absence of other liver diseases, a pregnancy-specific liver disease characterized by maternal pruritus without any skin rash. P23 region of chromosome 2, the gene-related with ICP has been reported. ${ }^{8}$

With satisfying maternal results, symptoms and abnormal liver function are spontaneously decreasing after delivery. It has been reported that the most successful pharmacological agent used in ICP treatment ursodeoxycholic acid (UCDA) (500 mg, twice a day or $15 \mathrm{mg} / \mathrm{kg} /$ day). ${ }^{9,10}$

There is a high percentage of perinatal morbiditymortality and it has been found that the rate of fetal complications like as preterm delivery, fetal distress, is increased in ICP. ${ }^{9,10}$ Fetal birth weights were properly with gestational age and it was reported that there was no difference in fetal malformation and abortion rates. The incidence of meconiumstained is $25-45 \%$ of the amnios. Intrauterine fetal losses, preterm birth, and acute fetal distress are encountered in $2 \%, 44 \%$, and $22 \%$ of in order of cases with ICP. ${ }^{11}$ High BA levels have a harmful impact on cardiomyocytes, a few experimental animal types of research have shown that. ${ }^{12}$ Therefore, ICP might stimulate foetal arrhythmia that may lead to stillbirth.

Thus far, both ideal time to delivery and prenatal management stay uncertain. No method to decrease their risk of fetal monitoring has been described to either predict adverse perinatal results. For time to deliver in ICP-complicated pregnancies is also unclear, and the advice of various national expert societies is different. It has to be considered that induction of labor is associated with a higher frequency of complications such as surgical delivery compared to spontaneous labor. ${ }^{13}$ Active management of labour protocols for ICP is recommended by the American College of Obstetricians and Gynecologists. ${ }^{14}$
In the study, it was aimed to report the maternal and fetal outcomes of women with ICP at our university hospital center.

\section{MATERIALS AND METHODS}

Ethical Status of the Study: Our study was approved by Erzincan Binali Yildirim University Clinical Research Ethics Committee (Data: 26/04/2021, decision no: 06/33). This study was carried out per the Declaration of Helsinki.

Pregnant women who presented with the complaint of itching, who did not have any liver and skin pathology, and increased bile acids $(\geq 10 \mu \mathrm{mol} / \mathrm{L})$ in the maternal blood, were considered as intrahepatic cholestasis of pregnancy (ICP). Demographic characteristics, liver enzymes, a gestational week at diagnosis, type of delivery, time of delivery, APGAR scores at birth, and newborn weight and information about the patients included in the study $(n=44)$ were obtained from hospital records.

Research Design: The study was performed retrospectively on 44 pregnancies complicated by ICP between June 2018 and December 2020, at our Education and Research Hospital, a tertiary care maternity center.

Cholestasis was diagnosed: by the

1. Onset second or third trimester of pregnancy pruritus and cholestasis

2. $\mathrm{BA} \geq 10 \mu \mathrm{mol} / \mathrm{L}$

3. Normalization of biochemical parameters after delivery

4. Absence of other diseases that cause pruritus

Also, to exclude other causes of liver diseases in all patients prior to the record, the serological analysis of viral hepatitis was done. Detected normal ultrasonography of the liver and biliary tract for all women, which performed ultrasonography.

Exclusion criteria were; liver viral infections, fatty liver of pregnancy, patients with chronic liver diseases, skin diseases, cholelithiasis and allergic disorders.

Statistical Analysis of Data: Statistical analysis was performed with IBM SPSS ver. 22 (Armonk, NY: IBM Corp). For categorical variables results were shown as count (n) and percentage (\%), for continuous variables as mean standard deviation or median (minimum-maximum) according to the distribution. Normality of the variables was checked with Shapiro-Wilks's test. Paired samples t test was used when comparing preop-postop hemoglobin and hematocrit levels. A p-value less than 0.5 was considered as statistically significant for all tests.

\section{RESULTS}

Maternal and fetal outcomes were evaluated in 44 women with ICP during the study period. 
Descriptive statistics are presented in Table 1 and Table 2.

Patient characteristics are shown in Table 1. Delivery type of $37(84.1 \%)$ cases was a caesarean section. Antenatal corticosteroid was given to 4 (9.1\%) of the women with ICP for the prevention of respiratory distress syndrome (RDS) in preterm infants. The number of primiparous women was $27(61 \%)$. In addition, 4 (9.1\%) women had preeclampsia and 4 $(9.1 \%)$ women had gestational diabetes mellitus (GDM).

The median week of delivery was 37 , and the median period of diagnosis to delivery interval was 1 week. One woman $(\% 2)$ delivered spontaneously at $\leq 36$ weeks' gestation. The number of fetuses with birth weight under $2500 \mathrm{~g}$ were 4 (9.1\%). Nine fetuses $(\% 20)$ had a $\mathrm{pH}$ of $<7.2$ level and they hospitalised in neonatal intensive care unit.

Only one of the neonates had Apgar at 1 and 5 minutes after birth, 0 and 0 respectively and this case was reported as intrauterine death with unknown ethology, which was in 38 gestational ages (Table $1)$.

The follow-up and delivery outcomes are presented in Table 2. Liver alanine transaminase (ALT) were lowest value 6 , and highest value 709 with median 59.5 (6-709). Aspartate transaminase (AST) value was 41.5 (10-923), and total bilirubin levels were 0.6 (0.3-10) in women. Hemoglobin values in Table 2 decreased after births in pre-post measurements and it was statistically significant $(\mathrm{p}<0.001)$. Similarly, hematocrit values also decreased, and it was statistically significant $(\mathrm{p}<0.001)$.

Neonatal mortality or neonatal morbidity such as sepsis, polycythaemia, hypothyroidism, neonatal convulsion, meningitis, pneumonia, pulmonary hypertension, pneumothorax, necrotizing enterocolitis, retinopathy of prematurity, congenital heart disease, intracranial haemorrhage, periventricular leukomalacia, congenital anomalies, metabolic diseases were not determined. Also, all women had eventless postpartum course.

Table 1. Socio-demographic parameters of the patients.

\begin{tabular}{|c|c|c|c|}
\hline & & \multicolumn{2}{|c|}{$\begin{array}{c}\text { Mean } \pm \text { SD or Median(min- } \\
\text { max) }\end{array}$} \\
\hline \multicolumn{2}{|l|}{ Age } & \multicolumn{2}{|c|}{$28.7 \pm 4.7$} \\
\hline BMI & & \multicolumn{2}{|c|}{$25.6 \pm 2.6$} \\
\hline Gravidity & & \multicolumn{2}{|c|}{$1(1-5)$} \\
\hline \multicolumn{2}{|l|}{ Parity } & \multicolumn{2}{|c|}{$0(0-3)$} \\
\hline \multicolumn{2}{|l|}{ Gestational age } & \multicolumn{2}{|c|}{$37(34-41)$} \\
\hline \multicolumn{2}{|l|}{ Birth weight } & \multicolumn{2}{|c|}{$2989.1 \pm 358.4$} \\
\hline \multicolumn{2}{|l|}{ Apgar1 } & \multicolumn{2}{|c|}{$8(0-8)$} \\
\hline \multicolumn{2}{|l|}{ Apgar5 } & \multicolumn{2}{|c|}{$9(0-10)$} \\
\hline & & $\mathbf{n}$ & $\%$ \\
\hline \multirow{2}{*}{ Alcohol drinking } & Never & 34 & 85.0 \\
\hline & Drinking & 6 & 15.0 \\
\hline \multirow{2}{*}{ Smoking status } & Non-smoker & 26 & 65.0 \\
\hline & Smoker & 14 & 35.0 \\
\hline \multirow{4}{*}{ Season } & Spring & 7 & 15.9 \\
\hline & Winter & 16 & 36.4 \\
\hline & Fall & 11 & 25.0 \\
\hline & Summer & 10 & 22.7 \\
\hline \multirow{2}{*}{ Type of Birth } & Caesarean & 37 & 84.1 \\
\hline & NSD & 7 & 15.9 \\
\hline \multirow{2}{*}{ Betamethasone } & No & 40 & 90.9 \\
\hline & Yes & 4 & 9.1 \\
\hline \multirow{2}{*}{ Preeclampsia } & No & 40 & 90.9 \\
\hline & Yes & 4 & 9.1 \\
\hline \multirow{2}{*}{ Gestational diabetes mellitus } & No & 40 & 90.9 \\
\hline & Yes & 4 & 9.1 \\
\hline \multirow{2}{*}{ Neonatal intensive care } & No & 35 & 79.5 \\
\hline & Yes & 9 & 20.5 \\
\hline \multirow{2}{*}{ Phototherapy } & No & 41 & 93.2 \\
\hline & Yes & 3 & 6.8 \\
\hline \multirow[t]{2}{*}{ Ursodeoxycholic acid } & No & 33 & 75.0 \\
\hline & Yes & 11 & 25.0 \\
\hline
\end{tabular}

Results were shown as Mean \pm SD or Median(min-max) for numerical data and as count (n) and percentage (\%) for categorical variables. 
Table 2. Patients' clinic and laboratory results.

\begin{tabular}{|l|c|c|}
\hline & $\begin{array}{c}\text { Mean } \pm \text { SD } \\
\text { or } \\
\text { Median(min-max) }\end{array}$ & \multirow{2}{*}{ p $^{*}$} \\
\hline Total bilirubin & $0.6(0.3-10)$ & - \\
\hline Direct bilirubin & $0.3(0-1.7)$ & - \\
\hline ALT & $59.5(6-709)$ & - \\
\hline AST & $41.5(10-923)$ & - \\
\hline ALP & $236.1 \pm 97$ & $<0.001$ \\
\hline Uric Acid & $4.3 \pm 1.4$ & $<$ \\
\hline Hemoglobin (pre) & $11.9 \pm 1.3$ & $<0.001$ \\
\hline Hemoglobin (post) & $10.7 \pm 1.2$ & \multirow{2}{*}{$<$} \\
\hline Hematocrit (pre) & $35.8 \pm 3.3$ & $<$ \\
\hline
\end{tabular}

ALT: Alanine transaminase; AST: Aspartate transaminase; ALP: Alkaline phosphatase; *p value of pre-op and post-op comparison; BMI: body mass index. Results were presented as mean $\pm \mathrm{SD}$ (standard deviation) or median (minimum-maximum); Paired samples $\mathrm{t}$ test was used when comparing preop-postop hemoglobin and hematocrit levels.

\section{DISCUSSION AND CONCLUSION}

Two extensive retrospective cohort studies conducted in Sweden and Australia recently reported positive results with regard to ICP. ${ }^{2,15}$ The study conducted in Sweden did not report the risk of stillbirth associated with ICP, but reported some increased risk of preterm birth, gestational diabetes and preeclampsia. ${ }^{2}$ Generally positive results associated with ICP, such as mild or severe results without stillbirth, were reported in the study conducted in Australia. ${ }^{15}$ A higher incidence of gestational diabetes, preeclampsia, and spontaneous preterm birth has been reported in women with ICP compared to the general population. ${ }^{15}$ These higher rates of preterm births compared to stillbirths should be taken into account in the management of ICP. In both cohort studies, no increase in stillbirth rate and high rates of preterm delivery was considered secondary to medical treatment. The American College of Obstetricians and Gynecologists (ACOG) recommends active management protocols for the ICP. ${ }^{16}$

In our study, $4(9.1 \%)$ women had preeclampsia and $4(9.1 \%)$ women had gestational diabetes mellitus (GDM) and the median week of delivery was 37, and the median period of diagnosis to delivery interval was 1 week. One woman $(\% 2)$ delivered spontaneously at $\leq 36$ weeks' gestation. In addition, one stillbirth was observed in our study.

A high serum bile acid concentration is essential for diagnosis. ${ }^{17}$ For women with ICP and markedly elevated $\mathrm{BA}$, defined as $>40 \mu \mathrm{mol} / \mathrm{L}$ and doubling of the levels of BA correlated with a $200 \%$ increase in risk of intrauterine fetal demise. ${ }^{18}$ Several studies showed treatment with UCDA did not seriously reduce the risk of their primary outcome, which was a composite of perinatal death, preterm delivery, or neonatal unit admission. ${ }^{19} \mathrm{We}$ observed that, ursodeoxycholic acid treatment was given to $11(20 \%)$ of the women with ICP in our clinic. Clinically, ICP associated with elevated serum levels of bile acids, and is often accompanied by elevation of serum levels of alanine aminotransferase (ALT) and/or aspartate aminotransferases (AST). In our study - liver alanine transaminase (ALT) was lowest value 6 , and highest value 709 with median 59.5 (6-709). Aspartate transaminase (AST) value was 41.5 (10-923), and total bilirubin levels were $0.6(0.3-10)$ in women.

One study reported that bile acids above $100 \mu \mathrm{mol} / \mathrm{L}$ were related to increased mortality despite twiceweekly antenatal testing. ${ }^{20}$ A study by Kohari et al. investigates the efficacy of an intensive surveillance system for women with total bile acids $>40 \mu \mathrm{mol} / \mathrm{L}$ at $<36$ weeks. The intensive surveillance included inpatient admission and continuous fetal heart rate (FHR) monitoring with delivery between 36 and 37 weeks. The authors reported a meaningful decrease in the stillbirth rate with this intensive surveillance strategy. $^{21}$

Most women gave birth at $\geq 36$ weeks' gestation in our study.

Delivery is mostly suggested at 37 weeks' without an amniocentesis for fetal lung maturity due to raised risk of fetal mortality, or after an amniocentesis for delivery prior to 37 weeks' gestation. If meconium is existing at the time of amniocentesis, delivery is indicated regardless of the fetal lung maturity results. Delivery can proceed without amniocentesis if the fetal monitoring is non-reassuring. Some providers are now waiting until 38-39 weeks gestation to deliver if there is the resolution of pruritus symptoms with treatment and bile acid levels are not significantly elevated ( $<40 \mathrm{micromol} / \mathrm{L})$.

Antenatal corticosteroid was given to $4(9.1 \%)$ of the women with ICP for the prevention of respiratory distress syndrome (RDS) in preterm infants in our study.

The ACOG, in their committee opinion detailing medically indicated late-preterm and early-term deliveries, recommends delivery at 36 to 37 weeks' 
gestation. They also state that delivery before 36 weeks may be indicated related to laboratory and clinical conductions. ${ }^{14}$

In our study maternal and fetal demographic data and results were evaluated in 44 women with ICP. Spontaneous preterm delivery and preterm delivery ( $\leq 37$ weeks gestation) rates were low. The incidence of SGA fetuses was low. Low preeclampsia and GDM rate were recorded. One perinatal death was observed, although no adverse maternal outcomes were observed.

In conclusion; The sample size and retrospective nature of our study limited the results. However, these concerns apply to all available literature on ICP. The incidence of ICP is low; this is the limiting factor for future studies. We believe it is necessary to clarify whether prematurity associated with ICP is because of spontaneous or iatrogenic preterm birth. Given that there is no substantial evidence to suggest that ICP increases the rate of stillbirths, we recommend that ICP be managed individually rather than a routine preterm delivery. The planned caesarean rate was significantly higher in ICP cases, regarding maternal outcomes. Increases the emergency caesarean was as result of induction of labour for women with ICP. At the same time, inadequate response to iatrogenic induction as a result of early labour, and fetal distress during labour in ICP more common causes leading to an increasing number of caesarean sections.

Ethics Committee Approval: Our study was approved by Erzincan Binali Yildirim University Clinical Research Ethics Committee. (Data: 26/04/2021, decision no: 06/ 33).

Conflict of Interest: No conflict of interest was declared by the authors.

Author Contributions: Concept - KU; Supervision - KU, FB, BA, PU; Materials -KU, FB, BA, PU; Data Collection and Processing -KU, YKA, TK; Analysis and Interpretation -KU, YKA; Writing - KU.

Peer-review: Externally peer-reviewed.

\section{REFERENCES}

1. Reyes H, Gonzalez MC, Ribalta J, et al. Prevalence of intrahepatic cholestasis of pregnancy in Chile. Ann Intern Med. 1978;88:487-493. doi:10.7326/0003-4819-88-4-487

2. Wikstrom Shemer E, Marschall HU, Ludvigsson JF, Stephansson O. Intrahepatic cholestasis of pregnancy and associated adverse pregnancy and fetal outcomes: a 12-year population-based cohort. BJOG. 2013;120(6):717-723. doi:10.1111/1471-0528.12174

3. Geenes V, Williamson C. Intrahepatic cholestasis of pregnancy. World J Gastroenterol. 2009;15 (17):2049-2066. doi:10.3748/wjg.15.2049

4. Abedin P, Weaver JB, Egginton E. Intrahepatic cholestasis of pregnancy: prevalence and ethnic distribution. Ethn Health. 1999;4(1-2):35-7. doi:10.1080/13557859998173

5. Lee RH, Goodwin TM, Greenspoon J, Incerpi M. The prevalence of intrahepatic cholestasis of pregnancy in a primarily Latina Los Angeles population. J Perinatol. 2006;26(9):527-532. doi:10.1038/sj.jp.7211545

6. Pata O, Vardareli E, Ozcan A, et al. intrahepatic cholestasis of pregnancy: Correlation of preterm delivery with even acids. Turk J Gastroenterol. 2011;22:602-605.

7. Yıldırım G, Aslan H, Gedikbaşı A, et al. In intrahepatic cholestasis pregnancy outcomes. Journal of the Turkish Society of Gynecology and Obstetrics. 2007;4:250-253.

8. Heinonen S, Eloranta ML, Heiskanen J, et al. Maternal susceptibility locus for obstetric cholestasis maps to chromosome region 2p13 in Finnish patients. Scand J Gastroenterol. 2001;36(7):766770. doi:10.1080/00365520119193

9. Bacq Y. Liver diseases unique to pregnancy: A 2010 update. Clin Res. Hepatol Gastroenterol. 2011;35:182-193. doi: 10.1016/ j.clinre.2010.11.011

10. Glantz A, Marschall HU, Mattsson LA. Intrahepatic cholestasis of pregnancy: Relationships between bile acid levels and fetal complication rates. Hepatology. 2004;40(2):467-474 doi:10.1002/hep.20336

11. Saleh MM, Abdo KR. Intrahepatic cholestasis of pregnancy: review of the literature and evaluation of current evidence. J Womens Health. 2007;16 (6):833-841. doi:10.1089/jwh.2007.0158

12. Gorelik J, Shevchuk A, de Swiet M, Lab M, Korchev Y, Williamson C. Comparison of the arrhythmogenic effects of tauro- and glycoconjugates of cholic acid in an in vitro study of rat cardiomyocytes. BJOG Int $\mathrm{J}$ Obstet Gynaecol. 2004;111(8):867-870. doi:10.1111/j.14710528.2004.00166.x

13. Lammert F, Marschall HU, Glantz A, Matern S. Intrahepatic cholestasis of pregnancy: molecular pathogenesis, diagnosis and management. J Hepatol. 2000;33(6):1012-1021. doi: 10.1016/s0168$8278(00) 80139-7$

14. ACOG Committee Opinion No. 764: Medically indicated late-preterm and early-term deliveries. Obstet Gynecol. 2019;133(2):e151-e155. doi:10.1097/AOG.0000000000003083

15. Marathe JA, Lim WH, Metz MP, Scheil W, Dekker AG, Hague WM. A retrospective cohort review of intrahepatic cholestasis of pregnancy in a South Australian population. Eur J Obstet Gyne- 
col Reprod Biol. 2017;218:33-38. doi:10.1016/ j.ejogrb.2017.09.012

16. ACOG committee opinion no. 560: Medically indicated late-preterm and early-term deliveries. Obstet Gynecol. 2013;121(4):908-910. doi:10.1097/01.AOG.0000428648.75548.00

17. Bicocca MJ, Sperling JD, Chauhan SP. Intrahepatic cholestasis of pregnancy: review of six national and regional guidelines. Obstet Gynecol Reprod Biol. 2018;231:180-187. doi:10.1016/ j.ejogrb.2018.10.041

18. Geenes V, Chappell LC, Seed PT, Steer PJ, Knight M, Williamson C. Association of severe intrahepatic cholestasis of pregnancy with adverse pregnancy outcomes: A prospective population -based case-control study. Hepatology. 2013;59 (4):1482-91. doi: 10.1002/hep.26617

19. Chappell LC, Bell JL, Smith A, et al. Ursodeoxycholic acid versus placebo in women with intrahepatic cholestasis of pregnancy (PITCHES): a randomised controlled trial. Lancet. 2019;394 (10201):849-860. doi:10.1016/S0140-6736(19) 31270-X

20. Herrera CA, Manuck TA, Stoddard GJ et al. Perinatal outcomes associated with intrahepatic cholestasis of pregnancy. J Matern Fetal Neonatal Med. 2018;31(14):1913-1920. doi:10.1080/14767058.2017.1332036

21. Kohari KS, Carroll R, Capogna S et al. Outcome after implementation of a modern management strategy for intrahepatic cholestasis of pregnancy. J Matern Fetal Neonatal Med. 2017;30(11):13421346. doi:10.1080/14767058.2016.1212833 